
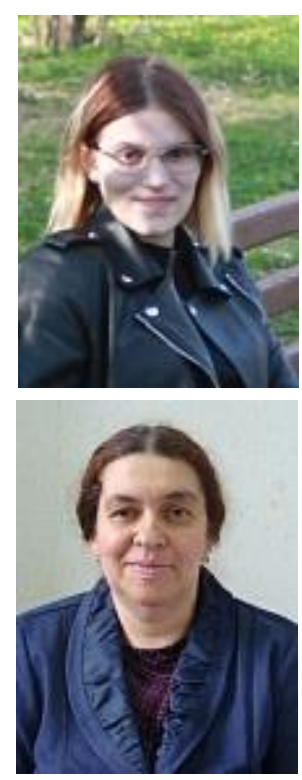

\section{МИКРОФЛОРА ЛЕЩА AВRAMIS ВRAМА (LINNAEUS, 1758) ОЗЕРА ВИШТЫНЕЦКОГО В ЛЕТНИЙ ПЕРИОД 2020 Г.}

\author{
Я. В. Мирошниченко, магистрант 2-го года, \\ e-mail: yana.miroshnichenko@klgtu.ru \\ ФГБОУ ВО «Калининградский государственный \\ технический университет» \\ Е. В. Авдеева, канд. биол. наук, проф., \\ e-mail: elena.avdeeva@klgtu.ru \\ ФГБОУ ВО «Калининградский государственный \\ технический университет»
}

С целью изучения микрофлоры леща оз. Виштынецкого, исследованием которого ранее никто не занимался, произведен микробиологический анализ его кожи, жабр и внутренних органов. Обнаружено доминирование в бактериоценозе леща оз. Виштынецкого бактерий рода Вacillus. Результаты наших исследований были сравнены с данными по микрофлоре леща Куршского залива, полученными сотрудником АтлантНИРО Н. Н. Чукаловой - выявлены различия в видовом и количественном составе бактерий изучаемых водоемов и количестве представителей условно-патогенной микрофлоры.

Ключевые слова: лещ, микрофлора, бактерии, среда обитания, оз. Виштынецкое, водоем, патогенность, промысловые рыбы

\title{
ВВЕДЕНИЕ
}

В современном мире, сильно подверженном негативному антропогенному воздействию, эпидемиологическое благополучие населения сильно зависит от санитарного состояния водоемов, как основных поставщиков пищевого сырья и питьевой воды. Его индикаторами служат группы условно-патогенных бактерий, количество которых тесно коррелирует с загрязненностью водоема, общим уровнем сапрофитов и содержанием органических веществ в воде. Именно поэтому проведение микробиологических исследований с целью установления этиологии кожных поражений и факторов, способствующих их проявлению является важным звеном при проведении не только ихтиопатологического мониторинга заболеваемости рыб, но и ихтиологических и экологических исследований в водоемах Калининградской области.

Лещ Abramis brama (Linnaeus, 1758) - пресноводная и полупроходная теплолюбивая рыба семейства Сурrinidae отряда Cypriniformes. Их представители обитают стаями в медленно текущих реках, низменных озерах с песчано-илистым и глинистым дном, встречаются в солоноватых заливах. Они предпочитают придерживаться глубоководных участков и располагающихся у крутых берегов ям, питаются путем всасывания донных организмов. Ареал обитания леща имеет широкое географическое распространение от Белого до южных морей Европы, в Калининградской области и Литве встречается повсеместно, включая маленькие озера и прибрежную часть моря [1-8]. 
Лещ играет важную роль в трофических цепях как бентофаг и часть пищевого рациона хищных рыб вроде судака и щуки. Является объектом промысла благодаря своим высоким пищевым качествам и относительно невысокой цене - его мясо содержит высококачественный белок, богато аминокислотами, жирами, витаминами и минеральными элементами. По данным ФАО [9], глобальный вылов леща в 2016 г. составил 48438 т. На прилавках его можно найти в свежем или замороженном виде, а по способу приготовления различают жареного, запечёного и приготовленного на пару.

В водоемах Калининградской области его микробиоценоз изучен пока слабо Е. В. Авдеева, О. В. Казимирченко, Н. Н. Чукалова и другие исследователи занимались определением количественного и видового состава микробиоценоза изучаемого объекта в Куршском, Вислинском заливах и некоторых водоемах Калининградской области. Авторами были выделены инвазионные представители, отмечена сезонная динамика бактериальной обсемененности и определены факторы, влияющие на качественный и количественный состав микрофлоры леща [10-12]. В Виштынецком озере таких исследований ранее не проводилось. По этой причине исследование микрофлоры леща озера Виштынецкого с целью определения видового состава, его патогенности и роли в возникновении бактериальных заболеваний для предупреждения их распространения является актуальной задачей.

\section{ОБЪЕКТ ИССЛЕДОВАНИЯ}

Объектом исследования является микробиоценоз кожи, жабр и внутренних органов леща, пойманного в Виштынецком озере летом 2020 г.

\section{ЦЕЛЬ И ЗАДАЧИ ИССЛЕДОВАНИЯ}

Цель работы - изучение обсемененности бактериями леща оз. Виштынецкого по индикаторным группам бактерий и сравнение полученных результатов с литературными данными о микробиоценозе леща из других водоемов Калининградской области.

Для достижения поставленной цели были выделены следующие задачи:

- исследование видового состава микробиоценоза леща оз. Виштынецкого;

- изучение обсемененности внутренних органов данного объекта;

- сравнение микрофлоры леща из оз. Виштынецкого и водоемов Калининградской области и обнаружение в ней условно-патогенных бактерий, которые могли бы вызвать бактериальные заболевания у рыб.

\section{МЕТОДЫ ИССЛЕДОВАНИЯ}

Клиническому осмотру и полному бактериологическому исследованию с изучением видового состава бактерий всех внутренних органов и тканей рыбы было подвержено 12 экз. леща. Отбор пробы произведен сотрудниками кафедры ихтиологии и экологии в июле 2020 г. из оз. Виштынецкого. Обработка материала проведена с использованием стандартных методик в ихтиопатологической лаборатории ФГБОУ ВО «КГТУ». Из микрофлоры леща было выделено 15 штаммов бактерий. Перед бактериологическим исследованием рыбу взвешивали на электронных весах, измеряли длину (зоологическую и промысловую).

Первичный бактериологический посев патологического материала проводили при помощи препаровальных игл, скальпеля, ножниц, пинцетов, чашек Петри, горелки и шпателя Дригальского. Материал для бактериологического посева (кусочек прижжёного исследуемого органа) отбирали с помощью стерильных инструментов, помещали в чашки Петри на рыбопептонный агар, растирали по поверхности шпателем и далее инкубировали в термостате при $37^{\circ} \mathrm{C}[13]$.

Для идентификации бактерий выделяли их чистые культуры - после появления обильного роста на чашках Петри, описывали культуральные признаки каждой колонии, которые перерассевали на скошенные агары и инкубировали в термостате при $37^{\circ} \mathrm{C}$. Далее 
изучали морфологические и биохимические признаки бактерий, проводили окраску по Граму [13].

После получения чистых колоний бактерий проводили ряд тестов на 15 различных по химическому составу дифференциально-диагностических средах для определения отношения выделенных бактерий к кислороду, выявления их подвижности, способности разложения углеводов в аэробных и анаэробных условиях до смеси кислот и газа, ферментации сахаров, образования сероводорода, редукции нитратов и другие [13]. На основании полученных после проведения тестов результатов, колонии бактерий определяли до вида с помощью определителей Берджи [14-15].

\section{РЕЗУЛЬТАТЫ ИССЛЕДОВАНИЯ}

Было проведено патолого-анатомическое и микробиологическое исследование леща из оз. Виштынецкого, при котором не было выявлено патологических изменений.

Нами изучена обсемененность кожи, жабр и внутренних органов леща путем выделения чистых культур бактерий и проведения ряда тестов. В микрофлоре леща из о3. Виштынецкого обнаружены 15 видов бактерий родов Bacillus, Alcaligenes, Acinetobacter, Corynebacterium, Veillonella, Pseudomonas, Enterobacter (табл. 1). Присутствовали сапрофитные бактерии, санитарно-показательная бактерия группы кишечных палочек, представители нормальной микрофлоры рыб и условно-патогенные бактерий - 73,3 \% обнаруженных видов являлись представителями нормальной микрофлоры рыб, 26,7 \% микробного пейзажа органов составили условно-патогенные виды бактерий, в их числе одна санитарно-показательная бактерия группы кишечных палочек Enterobacter nimipressuralis.

Таблица 1 - Определенные в составе микрофлоры леща виды бактерий и их локализация

\begin{tabular}{|l|l|l|}
\hline $\begin{array}{c}\text { № } \\
\text { 규 }\end{array}$ & \multicolumn{1}{|c|}{ Вид } & \multicolumn{1}{c|}{ Органы локализации } \\
\hline 1 & Bacillus brevis & Все органы, кожа и жабры \\
\hline 2 & Bacillus alvei & Все органы, кожа и жабры \\
\hline 3 & Bacillus circulans & $\begin{array}{l}\text { Кожа, кишечник, жабры, печень, сердце, желчный } \\
\text { пузырь, почки, селезенка }\end{array}$ \\
\hline 4 & Bacillus coagulans & $\begin{array}{l}\text { Кишечник, жабры, кожа, почки, селезенка, сердце, } \\
\text { желчный пузырь, почки, }\end{array}$ \\
\hline 5 & Bacillus badis & Кишечник, жабры, желчный пузырь, почки, селезенка \\
\hline 6 & Veillonella caviae & Кишечник, жабры, желчный пузырь, почки, селезенка \\
\hline 7 & Corynebacterium bovis & Кишечник, желчный пузырь, печень, селезенка \\
\hline 8 & Alcaligenes latus & Желчный пузырь, почки, селезенка, сердце \\
\hline 9 & Bacillus megaterium & Желчный пузырь, почки, печень, селезенка \\
\hline 10 & Bacillus firmus & Желчный пузырь, почки, печень, селезенка \\
\hline 11 & Pseudomonas putrefaciens & Желчный пузырь, сердце \\
\hline 12 & Enterobacter nimipressuralis & Почки, печень, селезенка, сердце \\
\hline 13 & Bacillus sublilis & Печень \\
\hline 14 & Bacillus authracis & Печень \\
\hline 15 & Acinetobacter lwoffii & Селезенка, сердце \\
\hline
\end{tabular}

Бактериоценоз леща в оз. Виштынецком был сформирован в основном представителями рода Bacillus (9 видов, 60 \%). Они входят в состав нормальной микрофлоры рыб, обсеменяли кожу, жабры и все внутренние органы, и попали в них из воды. В формировании состава микробиоценоза леща участвуют представители сапрофитной микрофлоры, которые могли попасть в микробиоценоз особей из воды и почвы - желчный пузырь, почки, селезенка и сердце были обсеменены бактерией Alcaligenes latus, в селезенке и сердце обнаружена Acinetobacter lwoffii. В микрофлоре внутренних органов 
присутствовали условно-патогенные для рыб бактерии родов Corynebacterium, Veillonella, Pseudomonas, Enterobacter, которые в неблагоприятных условиях могут спровоцировать вспышку бактериальных заболеваний у рыб, а при их употреблении без должной обработки у животных и человека. Условно-патогенные бактерии Corynebacterium bovis обнаруживались на слизистых оболочках или кожных покровах животных. Veillonella caviae могут быть обнаружены в ротовой полости, кишечнике и дыхательных путях человека и животных, они опасны из-за способности вызывать у них инфекционные заболевания. Условно-патогенная бактерия Pseudomonas putrefaciens способна вызвать бактериальную инфекцию, проявляющуюся в виде язв на коже ослабленных особей. Enterobacter nimipressuralis относится к бактериям группы кишечных палочек, которые являются санитарно-показательными микроорганизмами - ее обнаружение в микробиоценозе леща свидетельствует о бактериологическом загрязнении воды в оз. Виштынецком.

Наибольшей обсемененностью бактериями и разнообразием их видового состава обладала селезенка и желчный пузырь, в которых было обнаружено 12 (80 \%) и 11 (73 \%) видов бактерий соответственно. Менее всего была обсеменена кожа - на ней было найдено четыре вида бактерий, что составило 27 \% от всего полученного видового состава (рисунок).

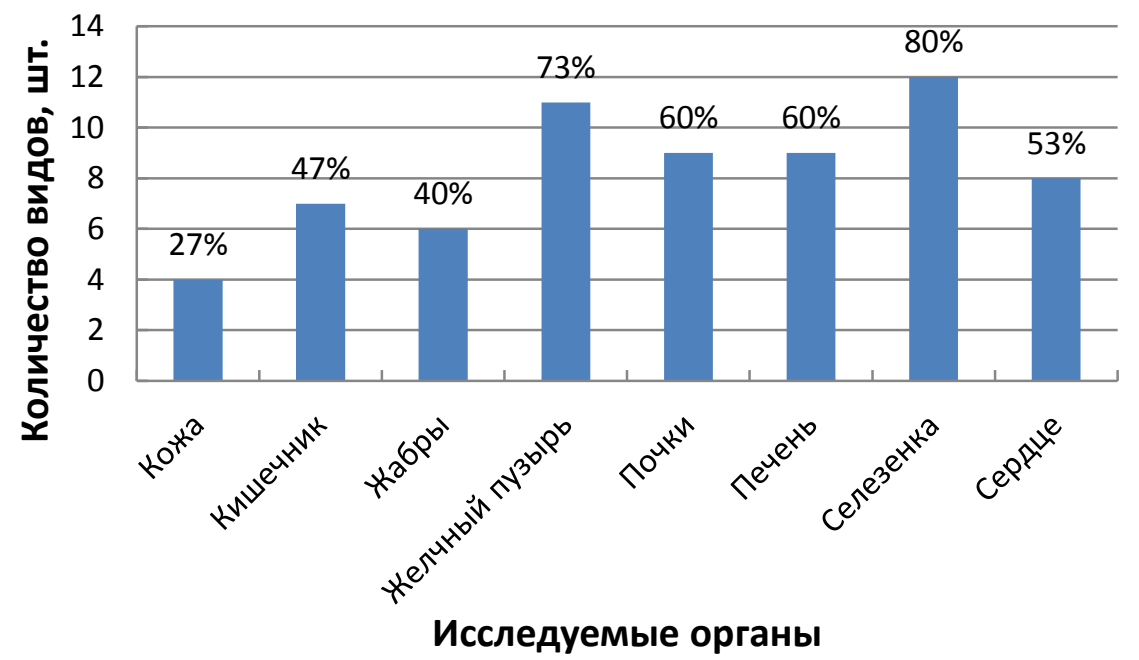

Рисунок - Обсемененность исследуемых органов по видовому составу

Также нами проведено сравнение с данными исследований микрофлоры леща Куршского залива, полученными сотрудником АтлантНиро Н. Н. Чукаловой [11]. Ею были выделены в микробиоценозе рыбы сапрофитные бактерии, бактерии группы кишечных палочек и условно-патогенные.

Микрофлора леща Куршского залива (по данным исследований Чукаловой Н.Н. [14]) была представлена 31 видом бактерий, принадлежащих к 14 родам. Среди исследуемых органов наибольшим разновидовым составом обладал кишечник (23 вида, 74,2 \%), меньшее количество видов было обнаружено в коже (18 видов, 58,1\%) и жабрах (17 видов, 54,8 \%), менее всего различными видами бактерий были обсеменены кожные язвы, кровь, печень, почки и селезенка леща с язвенным заболеванием (7 видов, 22,6 \%). Летом наиболее часто встречались бактерии рода Staphylococcus и Aeromonas (по 16,7\%), Pseudomonas, Micrococcus и Bacillus встречались в 12,5\% случаев каждая, Enterobacter и Proteus заняли по 8,3 \% от общего числа обнаруженных бактерий. Преобладали условно-патогенные виды, которых было обнаружено 20 видов $(64,5 \%)$, из них семь видов $(22,6 \%)$ являются санитарнопоказательными микроорганизмами группы кишечных палочек (БГКП) - полученные данные свидетельствуют о сильном микробном загрязнении Куршского залива.

При сравнении микрофлоры леща из Виштынецкого озера и Куршского залива выявлены отличия в общем количестве видов и их видовом составе, количестве представителей нормальной микрофлоры и условно-патогенных микроорганизмов, доминирующих группах обнаруженных бактерий (табл. 2). 
Таблица 2 - Сравнение данных по микрофлоре леща, выделенной из Виштынецкого озера и Куршского залива

\begin{tabular}{|c|c|c|}
\hline Показатель, ед. измерения & Виштынецкое озеро & Куршский залив [11] \\
\hline Общее количество видов, шт. & 15 & 31 \\
\hline $\begin{array}{l}\text { Количество видов представителей } \\
\text { нормальной микрофлоры, шт./\% }\end{array}$ & $14 / 73,3$ & $11 / 35,5$ \\
\hline $\begin{array}{l}\text { Количество условно-патогенных } \\
\text { видов бактерий, шт./\% }\end{array}$ & $4 / 26,7$ & $20 / 64,5$ \\
\hline $\begin{array}{l}\text { Количество санитарно- } \\
\text { показательных видов, БГКП, шт./\% }\end{array}$ & $1 / 6,7$ & $7 / 22,6$ \\
\hline $\begin{array}{l}\text { Доминирующая группа бактерий, } \\
\text { шт./\% }\end{array}$ & $\begin{array}{c}\text { Bacillus (нормальная } \\
\text { микрофлора) } \\
9 \text { / } 60\end{array}$ & $\begin{array}{c}\text { Staphylococcus (условно- } \\
\text { патогенная микрофлора) } \\
5 \text { / 20,8 }\end{array}$ \\
\hline
\end{tabular}

Сравнение микрофлоры леща из оз. Виштынецкого и Куршского залива показало, что бактериоценоз леща в Виштынецком озере представлен вдвое меньшим $(48,4 \%)$ видовым составом, на 40,0 \% меньшим количеством условно-патогенных и на 14,3 \% санитарнопоказательных видов бактерий, а также отличительной особенностью Виштынецкого озера является преобладание бактерий рода Bacillus среди представителей бактерий нормальной микрофлоры.

\section{ЗАКЛЮЧЕНИЕ}

Таким образом, согласно полученным в результате исследования кожи, жабр и внутренних органов леща оз. Виштынецкого данным, в микробиоценозе присутствовали сапрофитные бактерии, санитарно-показательная бактерия группы кишечных палочек, представители нормальной микрофлоры рыб и условно-патогенные бактерий - 73,3 \% обнаруженных видов являлись представителями нормальной микрофлоры рыб, 60 \% принадлежали роду Bacillus. Как показало сравнение наших результатов с литературными данными, преобладание рода Bacillus является отличительной особенностью о3. Виштынецкого от других водоемов Калиниградской области.

Видовой состав бактерий из микрофлоры леща оз. Виштынецкого оказался менее богатым и разнообразным на виды относительно Куршского залива, где обитает исследуемая рыба. Также было обнаружено меньшее, чем в Куршском заливе, количество представителей условно-патогенной микрофлоры и санитарно-показательных микроорганизмов БГКП, что свидетельствует о большем санитарно-эпидемиологическом благополучии исследуемого нами водоема.

\section{СПИСОК ИСПОЛЬЗОВАННОЙ ЛИТЕРАТУРЫ}

1. Семейство карповые [Электронный ресурс]. - Режим доступа: http://ecodelo.org (дата обращения 14.05.2020)

2. Жизнь животных: в 6-ти т. / под ред. Т. С. Расса - Москва: Просвещение, 1971. Т. 4, ч. 1. Рыбы. -655 с.

3. Тылик, К. В. Рыбы трансграничных водоемов России и Литвы / К. В. Тылик. Калининград: ФГОУ ВПО «КГТУ», 2007. - 128 с.

4. Биотехнический и производственный потенциал пастбищной аквакультуры на трансграничных водоемах России и Литвы: монография / Е. И. Хрусталев [и др.]. Калининград: Изд-во «ИП Мишуткина И. В.», 2009. - 198 с.

5. Аполлова, Т. А. Практикум по ихтиологии: учеб. пособие / Т. А. Аполлова, Л. Л. Мухордова, К. В. Тылик. - Москва: МОРКНИГА, 2013. - 338 с.

6. Кокуричева, М. П. Основные объекты товарного рыбоводства: методические указания для студентов зооинженерного факультета по направлению подготовки 111100.62, 111100.65 / М. П. Кокуричева. - Санкт-Петербург: СПб ГАУ, 2013. - 64 с. 
7. Иванов, А. П. Рыбоводство в естественных водоемах / А. П. Иванов. - Москва: Агропромиздат, 1988. - 367 с.

8. Никольский, Г. В. Частная ихтиология / Г. В. Никольский. - Москва: Советская наука, 1950. - 436 с.

9. Статистические данные по вылову леща [Электронный ресурс]. - Режим доступа: http://www.fao.org/fishery/species/2153/en (дата обращения 14.05.2020)

10. Каримова, Я. Р. Условно-патогенная бактериофлора леща (Abramis brama L.), воды и грунтов Куршского залива / О. В. Казимирченко, Я. Р. Каримова // Водные биоресурсы, аквакультура и экология водоёмов: вторая науч.-практ. конф., 15-16 октября 2014 г.: труды. - Калининград: Изд-во ФГБОУ ВПО «КГТУ», 2014. - С. 109-112.

11. Чукалова, Н. Н Экологические факторы, обуславливающие эпизоотическое состояние леща (Abramis brama L.) в Куршском заливе Балтийского моря: дисс.... канд. биол. наук: 03.00.16 / Чукалова Наталия Николаевна; ФГБОУ ВПО «КГТУ». Калининград, 2008. - 142 с.

12. Ларцева, Л. В. Микрофлора рыб и других гидробионтов / Л. В. Ларцева, О. В. Обухова, И. А. Лисицкая. - Астрахань: Издательский дом «Астраханский университет», 2008. - $107 \mathrm{c.}$

13. Авдеева, Е. В. Методы диагностики болезней рыб: учеб. пособие: в 2 ч. / Е. В. Авдеева, О. В. Казимирченко, М. Ю. Котлярчук. - Калининград: ФГОУ ВПО «КГТУ», 2010. - Ч. 1. Диагностика инфекционных болезней рыб. - 110 с.

14. Определитель бактерий Берджи: в 2 т. / под ред. Дж. Хоулта. - Москва: Мир, 1997. - Т. 2. -325 с

15. Определитель бактерий Берджи: в 2 т. / под ред. Дж. Хоулта. - Москва: Мир, 1997. - Т. 1. -432 с.

\title{
MICROFLORA OF BREAM ABRAMIS BRAMA (LINNAEUS, 1758) OF VISHTYNETSKY LAKE FOR SUMMER PERIOD 2020
}

\author{
Ya. V. Miroshnichenko, 2-year master student \\ e-mail: yana.miroshnichenko@klgtu.ru \\ Kaliningrad State Technical University \\ E. V. Avdeeva, PhD, Professor \\ e-mail: elena.avdeeva@klgtu.ru \\ Kaliningrad State Technical University
}

In order to study the microflora of the bream of Lake Vishtynetskoye, which no one had previously studied, a microbiological analysis of its skin, gills and internal organs was carried out. Dominance in the bacteriocenosis of the bream of Lake Vishtynetsky genus of bacteria Bacillus was found. The results of our research were compared with the data on the microflora of the Curonian Lagoon bream obtained by N. N. Chukalova, an employee of AtlantNIRO - differences in the species and quantitative composition of bacteria in the studied reservoirs and the number of representatives of conditionally pathogenic microflora were revealed.

Key words: bream, microflora, bacteria, habitat, water body, pathogenicity, commercial fish 